\title{
Critical Realist Philosophy and the Possibility of an Eco- decolonial Museology
}

Tom Jeffery

\begin{abstract}
New forms of museum practice that explore the dynamics of social and ecological processes as interlinked systems are increasingly urgent. Critical realist philosophy is used to consider the emergence of tensions between museological processes of decolonization and ecologization, and potentials for their resolution into a new form of practice, which is conceptualized as eco-decolonial. The analysis is focused on South African museums, but is contextualized within international theory and practice.
\end{abstract}

An exploration of the ontology of museum work surfaces a core tension in that trends towards a relational and emancipatory practice are paradoxically embedded within neoliberal ideology. Neoliberalism depends on and perpetuates the problematic human-nature dualism of the colonial era, and constrains the development of progressive social-ecological forms of museum practice. The analysis explores potentials for the resolution of this tension, in a contribution towards the transformation of the philosophical and theoretical frameworks of museum practice.

Key words: Museum practice; critical realism; decolonization; dualism; neoliberalism

This paper builds on an initial investigation into an absence of ecological issues from the practice of South African cultural museums (Jeffery 2017). Social responsibility is at the centre of the contemporary museum's mission, which implies the development of public programmes that engage with the cultural roots and social impacts of social-ecological crisis (Jeffery 2017: 20-1). Forms of museum practice with potential to explore the dynamics of social and ecological processes as interlinked systems seem increasingly urgent (Anderies et al. 2004: 2; Walker et al. 2004: 1; Jeffery 2017: 25).

Decolonization and ecologization of practice are current museological trends that seem to have particular relevance to this. The ecologization of museology refers to emergent transformative pathways that connect socially responsible practice to urgent ecological contexts. These emphasize fresh ways of thinking and being in order to disrupt the persistence of museological human-nature dualism, and to expand practice to emphasize the relationship between humanity and the environment as mutually constructive (Cameron 2015a: 16; Newell et al. 2017; Jeffery 2017: 21).

Generally, decolonization is about the empowerment and rehabilitation of marginalized peoples, knowledge and traditions (Dondolo 2005: 68-9; Alonso 2008: 249; Mdanda 2016; Newell et al. 2017: 11). The focus of South African museological decolonization is the vital amelioration of the depredations of the colonial and apartheid eras, an agenda of inclusivity, representivity and relevance, and the memorialization of trauma and difficult heritage (Corsane 2004: 6, 10; Mosely 2007: 101; Bakker and Müller 2010: 48; Meskell 2012: 6; MacDonald 2015; Jeffery 2017:23). Emergent international museological perspectives demonstrate an awareness of the entanglement of social and environmental justice, and some individual museums are engaged in progressive and creative practices that critique and transgress dualist museology in order to find ways to engage with crucial social-ecological issues (Plumwood 2002; Scott 
and Oelofse 2005; Allen 2015: 49; Nixon 2017; Phillips 2019). Such perspectives are largely absent from the South African decolonial museological programme (Jeffery 2017: 22). This article explores the emergence of tensions between decolonization and ecologization that seem to result in their separation in South African museum practice. It looks for potentials for their resolution towards a progressive form of practice suited to a global context of socialecological crisis. Such a form may be conceptualized as eco-decolonial.

The focus will be on South African national and provincial government-funded museums. These principal museological entities express the standards for national museum practice that emerge from ideology and policy. Connections will however be drawn between South African and international museum theory and practice, so that the South African may be expanded through the integration of emergent social-ecological perspectives, and may in turn contribute to international developments.

\section{Surveys and data analysis methodology}

The analysis is augmented through the input of key informants. Workers at national and provincial government-funded South African museums with at least five years experience in exhibition or education programming were selected for their potential insights into practice. 49 surveys were sent out and 15 were returned completed. Respondents were promised anonymity, and are referred to as Respondent 1, Respondent 2, etc. They answered a set of 13 open-ended questions that explore decolonial and ecological issues in museum practice. Similar to Vollgraaff's research (2018: 384), though the respondents cannot be considered representative of the museum sector, the consistency of the responses is indicative of challenges that South African museums face.

The survey data were analyzed through abduction, induction and retroduction. Abduction refers to the recontextualization of existing knowledge (Togo 2016: 89), in this instance drawing in themes, or codes, from a contextual analysis conducted in earlier work (Jeffery 2017). This initial exploration of policy and practice identified an absence of ecological issues from museum practice, generated by their absence from the policy framework, and a need to link ecological and decolonial concerns for meaningful transformations of museum practice. These constituted abductive codes for exploring the survey data here.

Induction refers to the identification of new codes from the data at hand, 'a process that ... helps us to [move] from a set of observations to a theory' (Sabai 2016: 182). Inductive analysis surfaced further codes as the survey data were analyzed. For instance, a number of respondents noted the alienating influence of quantitative management practice, so it is possible to induce that quantitative management practice is generative of alienation. Such general premises may inform changes to practice (Sabai 2016: 183). Other induced codes were commodification of practice, a restrictive authorized heritage discourse, and the suppression of staff agency and interest in social-ecological issues, as elaborated below.

These abducted and induced categories suggested the need for a new way of analyzing the emerging information that could offer a deep perspective on historical and structural causes. There was a need to bring the various experiences related in the survey data together with the information emerging from the literature review, and a critical realist laminated view (elaborated below) became useful for doing this in a way that allowed coherence and relationality (see, for instance, Munnik 2016: 307 on this 'constellational' critical realist perspective on open systems such as museum practice). This deepened the interpretation and analysis of these abducted and induced codes and provided a tool to consolidate a depth ontology analysis through retroduction.

Retroduction refers to 'inferential judgements from the analysis of indirect evidence' (Lotz-Sisitka and Price 2016: 6; Price 2016: 29). Drawing on O'Donoghue's insights (2016: $170)$, retroduction can be seen to offer a historical perspective on how practice changed over time to have the impacts and characteristics that it does today, with a focus on deep, generative, structural causes that offer 'a better explanatory grasp' of the research context (O’Donoghue 2016: 173).

The survey responses generally expressed resistance to structural restrictions on practice, such as the authorized heritage discourse and quantitative management, as elaborated 
below. There was a clear sense of frustration with the slow pace of transformation, and with the limitations on agency that emerge from the current governance structures of museum practice. Many survey respondents were critical of the focus on economic performance, surfaced below as emergent from an implicit neoliberal ontology, and the ways in which this in fact limits the processes of decolonization that governance structures claim to champion.

The responses had a clear focus on issues that relate to macro-level ideology and meso-level practice, which is to be anticipated as these are the levels at which the structural restrictions on practice emerge and are felt by the workers responding to the surveys. This is why the survey responses begin to appear at the meso-level, relatively late in the analysis below, and subsequently surface micro-, individual- and sub-individual-level perspectives on practice.

\section{Why critical realism?}

Progressive international perspectives and philosophies may enable deep theorizing about what a museology of social-ecological crisis might look like, and offer opportunities to deepen understanding of the links between social and ecological justice. The goal of this paper is to contribute to the philosophical and theoretical frameworks of South African and international museum practice. To this end, the philosophy of critical realism is proposed as 'underlabourer' for the theoretical development of an eco-decolonial museological practice.

Critical realism is notoriously complex, but valuable to the understanding of social structures and phenomena such as museums, and the mechanisms that steer practice in particular directions (Price 2016: 18; Lotz-Sisitka and Price 2016: 1). The philosophy of critical realism (henceforth $\mathrm{CR}$ ) offers 'explanatory tools and forms of reasoning that allow for making the complexities found in our contexts more visible and open for dialogue, engagement, learning and reflexivity' (Lotz-Sisitka and Price 2016: 5). Some key principles of CR philosophy that will be used in the analysis will be introduced below. Hopefully, their effectiveness in exploring the separation of decolonization and ecologization in South African museum practice (henceforth referred to as the $D$-E separation) will demonstrate that critical realism has potential to contribute to the emergence of progressive modes of museological theory and practice.

Fiona Cameron writes that the contemporary museum, with its persistent dualist foundation, is easily perceived as operating separately from society, focused too much on the past, and 'ill-equipped philosophically and ontologically' to face the challenges of a 'messy and turbulent world' (Cameron 2015b: 345). Given the philosophical and ontological challenges Cameron notes, the application of critical perspectives to the museum context is vital if museums are to remain socially relevant (Vergo 1989: 3; Smith 2014: 33). Vollgraaff's comprehensive survey of the content of South Africa's peer-reviewed museological journal, the South African Museums Association Bulletin (SAMAB), identifies no social-ecological themes, and concludes that South African perspectives are underdeveloped and lag behind international museological thinking (Vollgraaff 2018: 382-4; also see Levitz and Mathers 2000: 20; Martin 2000: 13). There is room for deeper engagement with the intellectual foundation of South African museum practice, while the term 'decolonization' is poorly understood in terms of what it means in practice. ${ }^{1}$ That is, there is a need to clarify and develop the philosophical and theoretical perspectives that underpin and shape decolonial practice.

In the international context, the influential 'New Museology' and its 'radical re-examination of the rôle of museums within society' (Vergo 1989: 3) was founded on postmodern principles of anthropocentric cultural pluralism (Cameron 2015a: 20). While the postmodern wariness of authority has been useful for museum work (Smith 2014: 33), critical theory has become disillusioned with the project of neoliberal postmodernity, its insistently relativist position, which has undermined curatorial articulation of visions for alternative futures (Wray 2019: 319), and its endless language games that have absented crucial environmental action (Martin 2000: 13-4; Potter 2001: 184; Keene 2006; Lotz-Sisitka and Price 2016: 6; Rosenberg 2020a: 203) ${ }^{2}$ The International Council of Museums' (ICOM) redefinition of the museum, furthermore, does not appear to be grounded in any particular philosophical or theoretical perspective. ${ }^{3}$ While South African museology lags international trends, there is equally a need for a revitalized 
philosophy for international museological theory and practice, one which may better support important emergent perspectives such as ecologization.

$\mathrm{CR}$ is, at least in part, a reaction to the ways in which postmodern relativism undermined potentials for the development of the concepts necessary for the understanding of vital, complex, open-systemic phenomena, such as climate change (Bhaskar 2010: 22). CR was developed to act as a philosophical 'underlabourer' for emancipatory social sciences (Bhaskar 2008: 335). Here it will be used to contribute to an emergent museology that is shedding fresh light on persistent, restrictive dualist structures (Cameron 2015a; Cameron 2015b; Newell et al. 2017). The analysis will use CR philosophy to explore museological human-nature dualism, and to surface new potentials to disrupt its constraints on practice and to contribute to an emancipatory museology that may bring greater freedom to 'humanity-in-nature' (Moore 2017: 598).

\section{Critical realism as underlabourer}

Underlabouring can be understood as 'the process of clarifying ... ontological and epistemological confusions and uncertainties [to support] a transformative research intent', or the practice of philosophy for real social-ecological change (Bhaskar 2008: 335; Bhaskar and Parker 2010: vii; Price 2016: 18; Rosenberg 2020a: 192). Through its capacity to elaborate a new level of ontological structure (Bhaskar 2008: 30), CR may help develop progressive museological perspectives suited to the practice context of social-ecological crisis.

CR specifically looks to the 're-vindication of ontology ... the philosophical study of being, as distinct from and irreducible to epistemology' (Bhaskar 2010: 1) to the extent that it 'stresses the crucial role that being (ontology) plays in our ... efforts to understand the way things are' (Norrie 2010: 7). As such, it has potentials to equip museums to meet the philosophical and ontological challenges that Cameron references, and further the museological goal of transformation towards the betterment of peoples' lives (Weil 1999; Ballantyne and Uzzel 2011: 87). CR is here proposed as underlabourer, as a philosophical support system, to the exploration and development of potentials for an eco-decolonial ontology, with the capacity to move museum practice from its persistent dualist framework and to resolve tensions such as those between decolonization and ecologization.

\section{Dialectical critical realism and the 'MELD' schema}

The CR oeuvre developed from basic critical realism to dialectical critical realism and later meta-reality (Lotz-Sisitka and Price 2016: 11). Basic critical realism became $1 \mathrm{M}$, the First Moment of the 'MELD' framework that structures dialectical critical realism. The present analysis will use basic critical realism to understand the initial emergence of the D-E separation and to surface potential transformational pathways to be developed in future work.

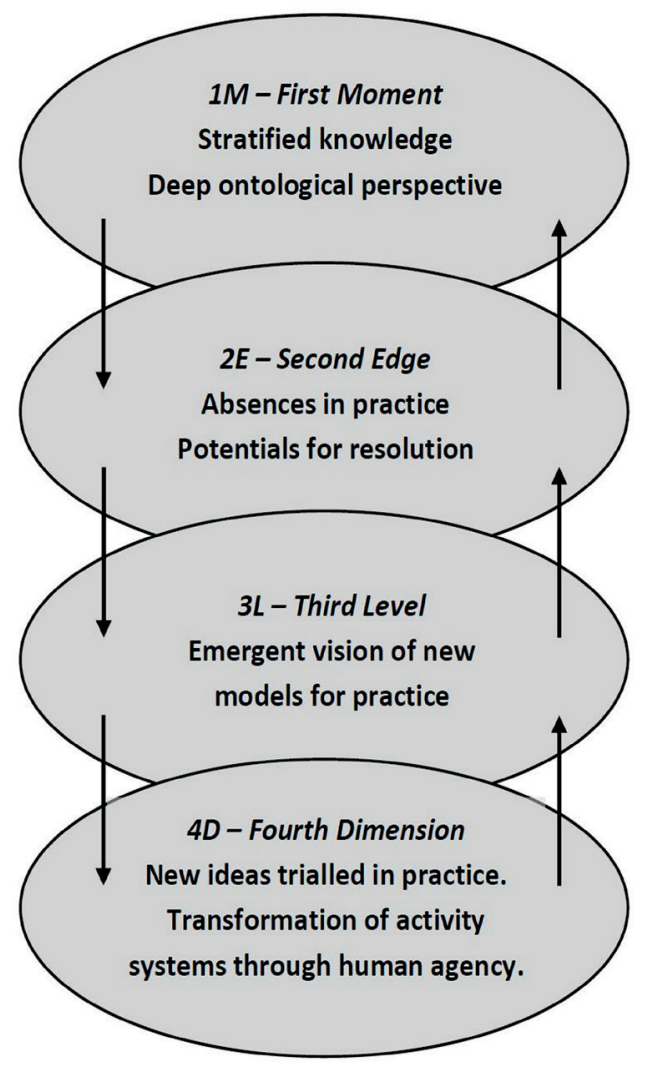

Figure 1. 'MELD' overview, Tom Jeffery 
'MELD' is 'a robust schema for investigating ... research contexts concerned with societal transformation', and a means through which normalized practice can be expanded reflexively (Hartwig 2008: xiii; Lotz-Sisitka 2016: 318; Schudel 2017: 163). It is a dialectical process that potentially removes constraints on transformation towards social-ecological justice (Bhaskar 2008: 38; Lotz-Sisitka 2016: 324; Mukute 2016: 196; Schudel 2017: 174, 179). MELD stands for first Moment (1M), second Edge (2E), third Level (3L) and fourth Dimension (4D) (Hartwig 2008: xiii). $1 \mathrm{M}$ enables a deep understanding of the status-quo (Bhaskar 2008: 196), and is elaborated below.

$2 \mathrm{E}$ is concerned with identifying absences in practice visible after the initial $1 \mathrm{M}$ analysis, and with the emancipatory agenda of the resolution of such absences towards the expansion of practice (Bhaskar 2008: 38; Lotz-Sisitka 2016: 324; Schudel 2017: 170). 3L develops the emergent vision of social-ecological justice in the open system that is being studied (Schudel 2017: 179). 3L imagines new models for practice, in this case, an eco-decolonial form of museum practice. $4 \mathrm{D}$ is the moment of real change, as the new ideas are tried in practice and human agency brings transformation to social structures through active resolution of social ills (Bhaskar 2008: 8; Mukute 2016: 196; Schudel 2017: 174). Figure 1 gives an overview of the MELD process, and the bidirectional arrows show its relational nature.

\section{$1 \mathrm{M}$ and depth ontology}

$1 \mathrm{M}$ explores 'the intrication of a multiplicity of explanatory mechanisms' that delineate the activities of social structures and agents (Bhaskar 2010: 6; Fletcher 2017: 181). 1M is focused on surfacing the deep mechanisms that drive the phenomenon that is being studied, in this case the emergence of the D-E separation and the ways it constrains potential for socialecological forms of museum practice.

CR initially conceives three levels of being, or 'ontological domains': the real (that which exists independent of human experience), the actual (the moment at which human experience 'discovers' the real and interacts with it), and the empirical (cultural mediation of the real and the actual) (Bhaskar 2010: 2; Price 2016: 18-9; Rosenberg 2020a: 197).

Higher [domains] of being are emergent from lower [domains]. ... [For] instance ... society [is] 'a real thing', emergent from the activities of people, but irreducible to the people who daily reproduce it, in the same way that climate is a 'real thing' that is emergent from the activities of the molecules of the atmosphere, but is not reducible to those molecules. We ... cannot fully explain [real] society by reducing it to the [actual] collective activities of empirical individual agents (Price 2016: 19).

The epistemic fallacy is the reduction of the domain of the real to the domain of the actual, and the reduction of ontology to epistemology, which 'functions merely to cover the generation of an implicit ontology' (Bhaskar 2008: 4; Bhaskar 2010: 1). That is, a powerful epistemology may take on or be given an ontological position. To disambiguate ontological and epistemological questions is to identify instances of the epistemic fallacy (Bhaskar 2010: 2). This can focus attention on deeper ontological issues that may underpin tensions such as that of the D-E separation and museological dualism, as will be explored below in the context of capitalist dualism and its neoliberal ideology.

CR views the world as constituted by open systems in which knowledge is always fallible (Bhaskar 2010: 3). This implies that causality cannot be reduced to constant conjunctions, but rather, 'phenomena are generated ... by a multiplicity of causal structures, mechanisms, processes or fields ... at different, including emergent, levels of reality' (Bhaskar 2010: 4-5). Real, open systems are thus characterized by stratification, or lamination, in which social structures (e.g. culture, traditions, heritage) and organizations (e.g. museums, governmental entities) operate in intersecting levels that interact in emergent ways (Bhaskar 1998: 8; Bhaskar 2010: 5; Lotz-Sisitka 2016: 320). Bhaskar created a model to guide researchers through these strata, which he called the seven laminations of scale, as follows:

1. The planetary (or cosmological) level concerned with the planet (or cosmos) as a whole... 
2. The mega-level of the analysis of whole traditions and civilizations, such as the South African trajectory from pre-colonialism, to colonialism, to apartheid, to independence...

3. The macro-level, orientated to understanding the way that whole societies or their regions function, such as the British economy...

4. The meso-level, studied by sociologists, which concerns the relations between functional roles such as manager and employee...

5. The micro-level [of production of social order between individuals], studied by ethnomethodologists and others...

6. The individual or biographical level, studied by existentialists and others.

7. The sub-individual psychological level, studied by psychologists and psychiatrists. (Bhaskar 2010: 9; Price 2016: 26).

The $1 \mathrm{M}$ lamination model enables a careful and structured approach to what is being revealed and helps researchers to avoid relativism through its perspective on the interconnected nature of the world (Rosenberg 2020a: 197). The lamination elucidates the generative mechanisms from which most social phenomena in open systems emerge (Bhaskar 2010: 3, 11; Frank 2010: 102), phenomena such as museum practice and its relations to society and ecology. This perspective avoids the reductive, linear, cause and effect philosophy of dualism (Cameron 2015a: 29) and enables a deep, retroductive understanding of emergence of phenomena through complex interactions (Bhaskar 2010: 8; Price 2016: 19; Mukute 2016: 192). Such a deep, ontological and reflexive perspective is just what seems to be needed in the museum context.

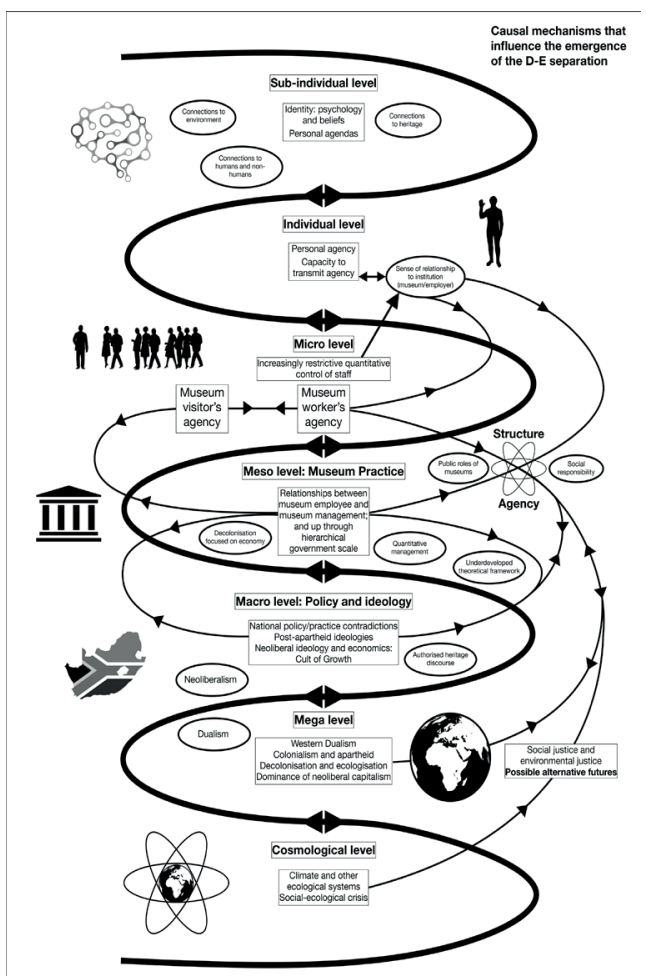

Figure 2 gives an overview of the seven levels and their elucidation of the $1 \mathrm{M}$ generative complex of the D-E separation, which is the focus of the remainder of this paper.

\section{$1 \mathrm{M}$ emergence of the separation of decolonization and ecologization}

The seven levels express 'a hierarchy of scale, that is of more macroscopic or overlying and less macroscopic or underlying mechanisms' (Bhaskar 2010: 9). The levels, however, are relational, as each level is emergent from but also influences those previous to it (Bhaskar 2010: 16; Price 2016: 26). The levels are not necessarily sequential, and influences can 'skip' levels, or surface from or shape more than one simultaneously. The vitality of emergence lies in its nature as a messy feedback process, and the strata should not be seen as a rigid structure of isolated steps and things that happen within each step. This analysis enters the lamination at the cosmological level and the 'overlying' level of natural systems and will try to express such relational complexities in the emergence of the $D-E$ separation. Relational movement is indicated by the dual-directional arrows in the main structure of Figure 2.

Figure 2. Generative Complex, Tom Jeffery 
'Critical realists designate the relation between structure and agency as the key framing device at the ontological level' (Scott 2010: 6), indicated by the flow of influences through the structure-agency nexus. Social structure pre-exists individuals, 'but is nevertheless emergent from agency (interactions) and is thus only relatively enduring', while individuals (agents) are born into pre-existing structure, and can then be either transformative or reproductive of that structure (Price 2016: 25). Society is thus 'both the ever-present ... material cause and the continually reproduced outcome of human agency' (Bhaskar 1998: 37). The D-E separation, the ideological separation of ecological justice from social justice, may be explored as a material cause of limited agency, which dualist museums and museum workers may be constrained to reproduce in their work in society. If the deep, structural causes of constraint are surfaced, this may enable agency for resolution of the constraints and transformation of the structure.

\section{The planetary (cosmological) level}

The Anthropocene has become a popular frame for understanding a geological age in which humanity affects global natural systems (Crutzen 2002: 23). The profound effects of global systems of capitalism, however, persuade some theorists to conceive the present age as the Capitalocene. This is 'a system of power, profit and re/production in the web of life ... [a] historical era shaped by ... a system that not only accumulates capital, but drives extinction' (Moore 2017: 594-7). Global capitalism is conceived as an ontological formation in which emancipation is impossible for the majority of humanity and the entirety of the more-thanhuman (Moore 2017: 601). The Capitalocene systems are of colonizing intent which, like their historical-colonial progenitors, 'vast and cool and unsympathetic, [regard] this earth with envious eyes' (Wells 1898: 1).

The Anthropocene perspective is embedded in the dualist logic that separates humanity from nature, while environmental justice concerns around unequal access to resources and unequal exposure to risk remain incidental (Nixon 2017: 24; Moore 2017: 595). The idea of the Anthropocene has been deeply valuable in popularizing understanding of human impacts on the planet, including in the emergent museological approach to ecological issues (see for instance Fox 2017; and Robin et al. 2017), but the idea of the Capitalocene surfaces capitalism's 'spaces of vulnerability and contradiction', (Moore 2017: 595) and may thus enable emancipatory strategies.

\section{The mega-level: Civilization}

This level offers a view of the historical context of international museum work, and of museological philosophy, theory and practice. An emergent critique of the dualist museological epistemology and the emancipatory potentials of new thinking and practices is grounded in awareness of interwoven human and non-human ecological communities, whose lives and freedoms are equally threatened by forces of inequality (Cameron 2015a: 16; Newell et al. 2017; Wehner 2017: 87; Jeffery 2017: 21).

The concept of neoliberalism as the primary organizing principle of international systems of governance, which then inform macro-level ideology and policy, may be elucidated at the mega-level. Economist Rajesh Venugopal argues that, despite its portrayal as a 'ubiquitous, totalizing and epoch-defining phenomenon', neoliberalism does not exist as a formal economic theory or practice, and as such there can be no meaningful referents for the critique of the concept by the 'other' social sciences (Venugopal 2015: 168-9, 180). He considers neoliberalism to be a rhetorical device, and that

there is for all practical purposes no such thing ... it is an artifice willed into existence ... by its critics ... outside mainstream economics [to] attach moral sensibility to a range of contemporary economic, social, political, spatial and cultural phenomena (Venugopal 2015: 181-2).

His criticism centres on the contradictions he sees in conceptions of neoliberalism (Venugopal 2015: 166). The only real access to economic theory and practice is through 'the mathematical sophistication of its theory and empirics', and neoliberalism is a lens through which the 'rest 
of' the social sciences may survey, simplify, label and render economics understandable, while 'what emerges ... is inadequate ... sketchy and vague' (Venugopal 2015: 180-1). In other words, capitalist economic 'empirics' are self-enclosed and inaccessible to the supposedly 'less sophisticated' social sciences.

The mathematical technicalities of capitalist economics may not be a part of the mental toolkit of the 'other' social sciences, but the visible impacts of an ethically bankrupt system of unequal exchange and accumulation in the real world certainly are, and it is these impacts that are the focus of their expression and critique of neoliberalism. Mathematical economic theory may be precise, but it bears little relation to the messy and violent practices of capitalism, which are inconsistent beyond the generation of maximum income for very few people in the short term (see for instance von Weizsäcker and Wijkman 2018: 63).

Venugopal's position can perhaps be understood in relation to 'the inability of... economic theory to understand power because of its mistaken ontological presuppositions', which do not conceive capitalism as a system of power relations (Palermo 2007: 539). That capitalism is indeed a violent and contradictory system of power relations can be seen in that it is simultaneously anthropocentric and dehumanizing, both historically and today. Colonialism was a system of simultaneous capitalist division and exploitation of people and nature. Humanity was separated from and classed as superior to Nature in order to allow Nature's exploitation by capital. Simultaneously, great numbers of people were classified as 'of Nature', rather than human, in order to allow their exploitation by capital. These violent dualist contradictions remain true in the era of neoliberalism (see for instance Plumwood 2002: 8 on 'our current failures and blindspots in relationships with nature'; Plumwood 2002: 9 and Moore 2017: 611-2 on cheap nature and labour, and who counts as 'human'; Nixon 2017). Rossi (2012: 349) considers that 'we arguably now lack understandings of ... capitalism as a totality [that] is constitutively multifaceted', because of the 'mutually contradictory ... ontologies of contemporary capitalism'. Contradiction characterizes capitalist ontology and practice, and this is why, across the landscape of the social sciences, the critical construction of neoliberalism as the capitalist ideology may seem contradictory, and is arguably necessarily so.

Neoliberalism is not merely a rhetorical device. In the present analysis it is taken to mean the ideology emergent from the contradictory ontology and the actual practices and impacts of dualist capitalism on the real world. This is potentially a conceptual basis for a social-ecological activist position for museum work, with capacity to directly challenge the neoliberal construction of 'real abstractions' such as Humanity, Nature, Society, the Economy (Moore 2017: 595). These construct human-nature dualism as a given condition of reality, and operationalize the violence of contradictory capitalism (Moore 2017: 601). They can be understood as instances of the epistemic fallacy, a broad treatment of epistemology as ontology that generates a screen of things that are 'obviously' or 'plainly' true and obscure neoliberal violence and injustice.

Venugopal's denial of the existence of neoliberalism can thus be read as an attempt to neuter the 'other' social sciences' critique of capitalism. Rosenberg (2020b: 2) echoes De Sousa Santos' (2018) position that such manipulations try to ensure that there is no alternative to the capitalist 'cognitive empire' that elevates its contradictory and violent epistemology to ontology in order to 'take away our ability to imagine or propose anything else without being made out to be wishful and irrational' (Rosenberg 2020b: 2). A critical eco-decolonial perspective will understand capitalist dualism as an epistemology elevated to the position of ontology, and neoliberalism as its global ideology. This enables a critical view on museological dualism as historically emergent from colonial capitalist dualism and perpetuated in the decolonial context by the contemporary dualism of neoliberal ideology. This offers a perspective on how these successive historical manifestations of capitalism impact the idea of the museum, are generative of the D-E separation, and restrict potentials for emancipatory museum practice.

\section{The macro-level: policy and ideology}

The macro-level South African heritage policy framework has a social justice focus on decolonization, but does not consider the social impacts of ecological crisis or potential synchronicities with environmental justice (Jeffery 2017: 22-4). This may be more deeply 
understood through mega-level neoliberal influences on the macro-level of ideology and policy. Attempts to 'forge a more social-democratic and co-ordinated variety of capitalism' after the end of apartheid failed amid a turn to international neoliberal macroeconomic policies (Nattrass 2014: 56, 57; Togo 2016: 93). The South African state's neoliberal policy framework is plagued by inconsistencies, and its practice by corruption, the net result of which is to exacerbate unemployment, for example, rather than to facilitate emancipation (Nattrass: 2014: 56; Adjor and Kebalo 2018).

The flow of neoliberal ideology from the mega- to the macro-level draws through the abstractions of the epistemic fallacy. The policy of the South African Department of Arts and Culture echoes the explicit mega-level international commitment to embed heritage within a neoliberal frame as part of the 'cultural and creative industries' (Thomas 2016: 37). ${ }^{4}$ Heritage is seen as an industry, in which 'optimal performance' is measured in relation to job creation, investment and economic growth as the solutions for social problems (Kamga and Heleba 2012: 83). ${ }^{5}$ This ensures that macro-level heritage policy is focused on a decolonization process operationalized through neoliberal economic principles that marginalize socialecological concerns.

The absence of social-ecological care from macro-level neoliberal ideology is apparent in sectors other than heritage. South Africa has progressive environmental policies, such as the National Environmental Management Act and the Climate Change Bill. ${ }^{6}$ These seem to be rhetorical, demonstrated by plans for new coal-fired power stations despite the government's pledge to reduce greenhouse gas emissions by 34 per cent by 2020 , which has not happened (Reddy 2013), and the continued allocation of huge amounts of water to mining despite high levels of water pollution by the industry, years of drought, and a widespread lack of public access to potable water (Molobela and Sinha 2012; van Rooyen et al. 2011). ${ }^{7}$ South African energy production parastatal Eskom protects its mismanaged monopoly by blocking the introduction of renewables, while the Mpumalanga province recorded the highest levels of nitrogen dioxide air pollution in the world, directly caused by Eskom's coal-fired power generation. ${ }^{8}$ About 23,000 people die in South Africa every year as a result of air pollution, and while the lockdown in response to the current global pandemic has reduced air pollution, it can still be anticipated to exacerbate the impacts of the Covid-19 virus. ${ }^{9}$ Rhetorical environmental policy serves as a supporting example of the exclusion of social-ecological perspectives from a practice underpinned by neoliberal ideology. Rhetorical environmental policy also has no agency with which to influence heritage policy.

It seems that macro-level decolonial policy thus proposes to counter the inequalities and violence of colonial dualist capitalism through the inequalities and violence of contemporary dualist capitalism. This paradoxical position undermines emancipatory decolonial potentials, and acilitates the appropriation of decolonial heritage into the neoliberal architecture of epistemic fallacies.

As mega-level influences flow into the macro-level of heritage policy, the emergent $D$-E separation reflects the complex contradictions of neoliberal ideology. To begin to resolve the separation is to begin to resolve the contradictions between emancipatory eco-decolonial ideals and the oppressive, profit-focused principals of neoliberalism.

\section{The meso-level of formal museum practice, and 5., the micro-level of social interaction}

As explained above, the survey data is introduced in the meso-level, as the responses had a clear focus on the structural restrictions that emerge from the macro-level, to be felt at the meso-level of practice by the workers who responded to the surveys. The responses surfaced meso-, micro-, individual- and sub-individual-level reactions to the restrictions on practice and agency that emerge from 'overlying' levels of power.

The meso-level considers how ideologies shape formal and functional roles in institutional practice, and the micro-level looks at social interactions and relationships (Price 2016: 27; Munnik 2016: 308; Togo 2016: 93). Neoliberal ideology emerges in the meso-level to govern formal practice relations between the institution (management) and employees, and determines the degree of agency workers may have to influence practice. 
The conditions of the meso-level flow into the micro-level of social relations. There, they affect the degree of agency museum workers may have in interactions with users and which they may transfer to users. The agency of museum workers, as the executors of the museum's social responsibilities, is the agency of the museum itself. The close entanglement of issues of structure and agency here enables a perspective on how meso-level organizational rules emergent from macro-level ideology impact vital micro-level face-to-face interactions. Respondent 3 speaks of how 'Good communication ... between the museum worker and the public ... has a very important transformative function. ... [It is] an opportunity to break down barriers'. ${ }^{10}$ This is an opportunity that may be seized or lost through the degree of agency provided by the ontological structure of the museum.

South African museum practice historically emerged from the mega- and macro-level colonial western modes of traditional dualist practice (Corsane 2000: 28; Abungu 2004: 4; Rall 2018: 11; Vollgraaff 2018: 374). This deep dualist structure is perpetuated through the contemporary influences of the authorized heritage discourse (AHD), which legitimates the values and validated practice of a given heritage context and can be understood as a set of ideological expectations which are, in turn, legitimated by museums themselves when they adopt its values (Herbert 2000: 83; Khan 2000: 50; Vollgraaff 2012; 31; Pendlebury 2013: 709; Jeffery 2017: 22). The AHD is a vehicle through which the paradox of neoliberal ideology, as the vector for the decolonization of heritage, passes from the macro- to the meso-level and becomes engrained as the implicit ontology of museology. The absence noted above of social-ecological perspectives from the South African Museums Association Bulletin seems likely to result at least in part from such ideological limitations on practice and research.

Neoliberal constraints on the agency of the museum and museum workers can be identified in the commodification of heritage practice, which constitutes a postcolonial reproduction of colonial hegemonies of growth, and constrains sustainability initiatives in favour of profitability (Helland and Lindgren 2016: 433; Togo 2016: 93). The close association of heritage with tourism may reinforce and exploit cultural stereotypes as these are transformed into a consumable spectacle, while governance structures see museums as tourist sites and not as knowledge-generating institutions (Rassool 2000: 6-10; Witz et al. 2001: 280; Marschall 2005: 103-4; Soudien 2008: 215; Vollgraaff 2018: 386). The iconic Robben Island Museum, for instance, 'is like a huge sausage factory: get as many tourists on and off the island and don't worry if the layered history of the island is lost. As long as the money comes in, it doesn't matter'.11

In another example, 'official memory' emerges as meso-level values of political and economic elites morph the AHD into a set of hegemonic narratives, evident in the political manipulation of the practice of memorialization (Abungu 2004: 3; Shoba 2005: 26; Bakker and Müller 2010: 50; Rankin 2013: 79, 90; Zuma 2018: 40; Roux 2018: 408-9).12 The political apparatus of state power possesses the means to turn cultural capital into political power (Mahony 2017: 128). Official memory can be understood in terms of the focus of authoritarian capital on the material interests of politically powerful economic elites, which can be generative of patrimonialism and corruption (Nattrass: 2014: 56; Venugopal 2015: 174). 'Museums in South Africa are under pressure to adhere to a single, authorized narrative of the past and the present' (Vollgraaff 2018: 385), a narrative which constitutes a selective discourse of heroic leaders, of survival, triumph and exemplariness, and silences and alienates dissonant voices and communities (Rassool 2000: 11; Dubin 2006: 238; Soudien 2008: 214; Bakker and Müller 2010: 49-50; Mngqolo 2010: 70; Rassool 2016: 196). The museum is instrumentalized in the construction of a specific identity, which absents deeper treatments of the 'less remembered miseries and celebrations of township life' (Soudien 2008: 211), as well as narratives that may surface contemporary social-ecological injustices.

Respondent 5 feels that 'Museums have become very focused on liberation heritage and government goals to the detriment of grassroots voices and non-political issues'.13 'Politicians have had too much of an input regarding what museums should/should not consider their business', ${ }^{14}$ while 'Many (politically-correct) temporary displays have been completed but this is not a good reflection [of decolonization]. ${ }^{15}$ Equally, when a museum tacks on a token 'Struggle Room'16 this limits the learning opportunities offered to communities and does no justice to the layered memory of anti-apartheid movements (Soudien 2008: 211). 
Authorized heritage narratives and official memory can also undermine the crucial role of arts and culture in social critique, and potentially discriminate against niche, experimental or radical programmes (Mahony 2017: 130-1). Such circumstances impede broad community connections to a museum. ${ }^{17}$

Perhaps the most significant effect of neoliberal ideology on museum practice is the emergence of quantitative management practice, the strategic focus of museum management on rigid quantitative performance indicators, logistics, administration and Treasury compliance requirements (Vollgraaff 2004: 2; Dubin 2006: 217; Vollgraaff 2018: 373, 384). The demands of compliance to regulatory bodies overshadows museological functions,$^{18}$ and energy is placed on economic measurements instead of effective museum services (Vollgraaff 2018: 377-87).

Museum and heritage workers' practice goals and any feedback into the management system are formally limited to the numerical. Qualitative ideals and ideas and potentials for creative worker-driven expansion of museum practice are absented by the limitations of economically correct practice. Respondent 5 feels that there is a need to weaken the focus on managerialism and measurable outcomes and to reward experimentation and creative thinking, ${ }^{19}$ while Respondent 2 emphasizes that:

Bureaucracy itself is deeply colonial ... Productivity is the only important factor and employees are seen as a troublesome group who want too much money for too little work. This type of 'us' and 'them' mentality creates another binary which is the hallmark of colonization. ${ }^{20}$

Neoliberal quantitative management thus tends to consolidate dualist thinking and alienates workers (see Mahony 2017 on activist interventions in cultural institutions in resistance to capitalist 'corporatization' of practice). Museum governance at the macro- and meso-levels seems to be largely divorced from the museum's (theoretical) meso- and micro-level social obligations, just as neoliberal ideology is largely divorced from the lived reality of a world in social-ecological crisis (see, for instance, Hawkins 2009: 50 on how the brand value of the notorious plastic bag outweighs its ecological impacts).

The reciprocity of the structure-agency relationship at the institutional level thus seems to be biased towards political and ideological structures that have more power and limit the agency of workers. That is, individuals at the meso- and micro-levels are constrained in such a way that they are reproductive of structure. 'What we have learned from museum educators worldwide is that what matters most is the belief that museums can be the agents of socioecological change'; ${ }^{21}$ however, the structural limitations on the agency of museum workers and museum users cannot support the emergence of emancipatory social-ecological impulses. The paradox of neoliberalism as the driver of emancipatory potentials flows from the 'overlying' levels into practice to become the heart of the D-E separation, and neutralizes potentials for social-ecological justice. Through such contradictions neoliberalism appropriates decolonial practice so that, like policy, it becomes an element of the capitalist architecture of epistemic fallacies that precipitates the D-E separation.

This is a strong motivation for an eco-decolonial perspective that may act as a philosophical and theoretical foundation from which museum practitioners may talk back to powerful overlying forces, and their meso-level expression in commodification, official memory, and quantitative management practice. This may facilitate deeper interrogation of the paradox of neoliberal ideology as the driver for the emancipatory impulses of decolonialism, and the ways in which this absents social-ecological perspectives and perpetuates dualism.

Despite emergent international trends towards ecologization, however, dualist practice frames remain firmly entrenched. The International Council of Museums (ICOM) is redeveloping its definition of the museum in order to better address contemporary challenges. ${ }^{22}$ Collection is considered sacrosanct in the redefinition process:

The museum definition should retain ... the unique, defining and essential unity in museums of the functions of collecting, preserving, documenting, researching, exhibiting and in other ways communicating the collections ... The word museum is easily understood in its manifold complexity, with a stable core concept of a collection. ${ }^{23}$ 
The full scope of a museum's practice activities emerges from collection. Collection is conserved at the heart of the museum's dualist practice frame, which may perhaps be understood in light of the fact that, despite the need for museum practice to be rooted in critical theory, '[For] the museum worker ... the practical project tends to start from, and stop with, the object' (Thomas 2010: 7).

Collection is thus the grounding ontological activity of museum work. Collection practice is rooted in historical museological dualism, which the implicit neoliberal ontology both fixes and exploits in contemporary practice. This is the deeper underlying mechanism for the persistence of human-nature divisions in the work that museums do. While the methods of collecting, and of interpreting and exhibiting collections are the focus of critique, reflection, and change (Pearce 2003; Morgan and Macdonald 2020), even in the context of discussions about redefining and reinventing the museum to ensure its future, there is little critique of the principle of collection as the defining activity of the museum. Collection seems to be exterior to change, because it is so fundamental to what a museum is conceived to be. To reshape museum practice, however, seems to require a fundamental reimagination of the implicit museological ontology, and thus of the grounding ontological activity, collection. This is a crucial element of the emergence of an eco-decolonial form of practice.

\section{The individual or biographical level}

This is the stratum of individual agency and the potential capacity for expression of the personal psychological agendas defined at the sub-individual level. The museum worker's sense of their relationship with the institution may be empowering or disempowering, both personally and in relationships with users of the museum.

Most respondents expressed personal concern at the global social-ecological crisis as a threat to 'the survival of the human race and the earth system as a whole', ${ }^{24}$ 'a crisis from which we cannot return if we do not address our waste problems such as plastics, waste water, carbon footprint, etc., now'. ${ }^{25}$ Respondent 1 felt that it is important for museums to emphasize the ecological cost of cultural practices, ${ }^{26}$ while 'Protection of the environment ... is key to sustainability. ... Cultural museums need to play their role towards realization of a sustainable society'. ${ }^{27}$ In a nuanced critique of dualism, one respondent noted that 'we do not see non-humans as beings with their own interests'. ${ }^{28}$

There is thus a tension between respondents' individual, progressive social-ecological concerns and the neoliberal ideology of the institutions for which they work. This tension flows through the structure-agency nexus to influence individual senses of agency and value, and also generates potential for museum workers to talk back to the contradictions of the overlying levels and disrupt practice constraints.

A potentially powerful perspective views decolonization not as an institutional process, but as a form of personal reflexivity and agency:

Decolonization asks us to deeply introspect and explore the biases which we all have and which affect how we ... treat other people in various environments.... Looking outside of oneself and working for the good of the future generations is ... part of decolonization, because your community and society are a part of you and are as important as the individual. ${ }^{29}$

In this sense, decolonization may be considered as a personal, reflexive openness to others' perspectives. Reflexivity may counter personal biases and underpin a critical counterpoint to personal or institutional political agendas. The generation of agency for such reflexive, individual sensibilities may potentially contribute more effectively to institutional decolonization than neoliberal quantitative practice. The development of such potentials could become a key element of an eco-decolonial philosophy and theory for museum practice.

Impetus towards multi- and inter-disciplinary practice has gained new urgency as a catalyst for emergent social-ecological practices (Bhaskar 2010: 4). To disrupt 'disciplinary purity' is particularly crucial for museums in their movement towards relational modes of practice that are better able to engage with entangled decolonial and ecological demands (Phillips 2019: 331), and the value of interdisciplinary approaches was emphasized by respondents. 
Knowledge is not confined to a specific field, but overlaps and flows through various aspects of the disciplines.... Museums are ... open to multi-disciplinary work. ... Museums cross disciplinary divides ... created during colonial times ... and an important aspect of decolonization is the interwoven nature of knowledge. ${ }^{30}$

Interdisciplinarity may be envisioned as the disruption of the boundaries that define traditional practice, in order to encourage new ways of thinking. ${ }^{31}$ This may generate links between specialists in various fields, ${ }^{32}$ and develop collaboration with the communities of practice in various disciplines. ${ }^{33}$ It may enable museums to develop programmes that disrupt dualism as they 'better combine humanities and natural sciences', ${ }^{34}$ so that 'ecological issues are not seen as remote scientific ideas, but issues that affect how we live. Our culture affects our environment and the state of the environment affects our culture'. ${ }^{35}$

'Studying the natural world is a cultural activity. Science is a cultural activity', ${ }^{36}$ an understanding which is key to the disruption of dualism. Cultural museums potentially 'provide an ideal bridge between culture, social history and science', ${ }^{37}$ which offers an opportunity for museums to explore the entanglement of humanity with nature:

People, culture, customs, everything we do, create or use is linked to our interaction with nature. We create things in order to survive our environment, we use things to control our environment. We have ways of doing things because of our environment, our customs are mostly based on what is available in our environment. We are part of nature. ${ }^{38}$

'Culture is rooted on [sic] nature. There is no way that the two can be separated', ${ }^{39}$ to the extent that, 'We are one, part of nature'. ${ }^{40}$

There are clear tensions between individual and institutional positionalities on socialecological issues. South African museum workers demonstrate nuanced perspectives with potential to disrupt the constraints on practice of the neoliberal ontology that underpins the D-E separation. Such perspectives may open transformative pathways for museum practice, but are absented by the institution-individual binary and limited communications channels created by quantitative management. An eco-decolonial museum practice would look for ways to realign the structure-agency nexus to enable greater agency in practice for such progressive individual level perspectives.

\section{The sub-individual psychological level}

The sub-individual level is focused on personal psychology and personal agendas (Price 2016: 27; Togo 2016: 88, 91). This is the level of a person's emotions, their sense of their connection to their heritage, to their environment and to other living things, and the level of personal interest or lack of interest in decolonization and/or ecologization.

At the sub-individual level, respondents reflected on their senses of agency in relation to the deep problems they encounter in the world. Mega-level issues of 'Climate change, global warming, extreme weather, population pressure, scarcity of resources', and the macro-level 'inability of governing systems to lessen the rich-poor divides or enable social justice', bring about 'information overload and mistrust on the level of the individual's ability to experience them. It does not make it less real, but it makes one feel more useless'. ${ }^{41}$ This seems to be an expression of a sense of ineffectiveness that people may feel when they are faced with 'wicked problems' such as social-ecological crisis, problems that lack simplistic solutions and straightforward planning responses, and which are complex and ambiguous and often embedded within controversy around what needs to or can be done (Lotz-Sisitka et al. 2015: 73; Colding et al. 2019: 512).

This sense of ineffectiveness may be deeper when the person is embedded within an institutional structure that is rooted in neoliberalism and its quantitative tentacles, which limit individual and collective agency. Such structures are attuned to neither individual nor sub-individual reactions to wicked problems, nor to the potential development of creative approaches to their resolution at these or overlying strata. For museum workers to feel a deep sense of agency and value requires 'a fundamental shift in how work is done and how museum employees view themselves. Value can only come from ... proper management 
providing employees with a feeling of agency and autonomy.... Fundamentally museum staff need to be valued'. ${ }^{42}$ This sense of value effects responses to wicked problems, and their emergent causes and effects through the levels of the lamination.

The expression of individual psychologies and values can surely be seen in the respondents' considered comments, which indicate a depth of interest in the contradictions at hand and a commitment to their resolution.

\section{Conclusions}

The goal of this paper is to contribute to the philosophical and theoretical framework of museology and to surface potential new transformative pathways for museum practice. It envisions the possibility of an eco-decolonial mode of thinking that may resolve the separation of decolonization and ecologization of practice in South African museology and disrupt the persistence of international museological human-nature dualism at the ontological level.

The philosophy of critical realism offers value as underlabourer for the expansion of museum theory and practice. The critical realist $1 \mathrm{M}$ analysis surfaces the deep generative roles of capitalism and neoliberalism in the ideological formations that shape museum practice. CR philosophy shows how neoliberalism, rather than just a difficult context for practice, in fact becomes the implicit ontology of museology. The laminated perspective shows how this happens historically, through the co-evolution of dualist museology and dualist capitalism, from the cabinets of curiosity of European colonial capital through to the museum as a social enterprise in the contemporary era of neoliberal capital.

Just like colonial capitalism, neoliberal capitalism is operationalized through humannature dualism (Moore 2017: 597). As the implicit ontology of museum practice, neoliberalism is at the root of the persistence of museological human-nature dualism. The ontological and epistemological contradictions of neoliberalism flow through each level of the $1 \mathrm{M}$ lamination. They move from ideology and policy into practice through the authorized heritage discourse, and are associated with constraints on museum practice such as official memory and quantitative management practice, which limit the agency of museum workers and of museums themselves and signal a fundamental problem for museum work: how to be socially and ecologically responsible within a governing system that depends on not being so.

Most significant for museum work, however, is the paradox of the oppressive ideology of neoliberalism positioned as the fundamental driver of the emergent, emancipatory, relational museological impulses of decolonization and ecologization. Emancipatory practices cannot be supported by the neoliberal ideology that generates and perpetuates the inequalities and injustices of the Capitalocene. Rather, emancipatory principles and practice are appropriated by neoliberal ideology, for instance through the commodification of practice, so that they become part of the complex architecture of epistemic fallacies through which the epistemology of neoliberalism represents and protects itself as the essential global ontology.

The idea of a practice driven by neoliberal authority, however, implies the possibility of transgressive discourses and activist practices. Transgression and activism may emerge from the understanding that epistemic contradictions, such as 'emancipatory neoliberalism', are also vulnerabilities (Moore 2017: 595).

Neoliberalism is the implicit ontology of museum practice. Collection is the grounding ontological activity of dualist museum work. Collection is thus at the heart of the fault-line between museological tradition and progress, between entrenched and emergent modes of practice. To reflect on collecting as a principle is to reflect on the core of the museum. In ICOM's redefinition process, however, the principle of acquisition is isolated from critique. ${ }^{43}$ This effectively applies a philosophical shield to the deep roots of museological dualism in neoliberalism. To disrupt the untouchable position of the principle of collection may enable the fresh perspectives necessary for deep transformation of museum philosophy, theory and practice.

To unsettle acquisition's fundamental ontological position is entangled with a second potential pathway, the recalibration of the structure-agency nexus. The CR perspective on a reciprocity between workers' individual, progressive 'underlying' positionalities and neoliberal institutional 'overlying' positionalities may be operationalized. Workers may assume 
the agency to conduct activities with potential to change practice and disrupt the implicit neoliberal ontology. Such 'interstitial' activism by museum workers, activism from within the ontological formation so that it may be 'opened up' from the inside, should be seen 'not as an attack on these public institutions for their duplicitous value systems, but as acts of love for what they could be' (Mahony 2017: 132-3). Workers' perspectives on 'the living, multispecies connections of humanity-in-nature and the web of life' (Moore 2017: 598) may resist the appropriation of museum practice into the neoliberal epistemic architecture, disrupt the division of humans and nature into discrete abstractions, and challenge the simultaneously anthropocentric and dehumanizing impulses of neoliberalism. In doing so, workers' agencyactivism may contribute to a relational practice that will link social and environmental justice. Such an eco-decolonial perspective may disrupt dualist historical trajectories, and focus on the ways in which the amelioration of the colonial depredations of the past is entangled with the amelioration of the social-ecological crisis of the present.

Forthcoming work will develop the ideas emergent from the $1 \mathrm{M}$ analysis through the subsequent phases of the critical realist dialectical framework, and further explore the potentials of an emancipatory eco-decolonialism, to contribute to the reimagination of the ontology of museology and the deep transformation of the museum.

Received: 19 August 2019

Finally accepted: 1 October 2020

\section{Notes}

1 Respondent 5, interview by author, typed questionnaire, 10 May 2018, Cape Town.

2 Alison Gibbons, 'Postmodernism is Dead. What Comes Next?', Times Literary Supplement Online 3 October 2019. https://www.the-tls.co.uk/articles/postmodernism-dead-comesnext/, accessed 14 February 2020.

3 Jette Sandahl, 'International Council of Museums Standing Committee for Museum Definition, Prospects and Potentials: Report and Recommendations', International Council of Museums 19 June 2018. https://icom.museum/en/activities/standards-guidelines/ museum-definition/, accessed 14 October 2019.

4 Department of Arts and Culture, 'Revision of the Department of Arts and Culture 1996 White Paper', 2017. http://www.dac.gov.za/white-papers, accessed 20 May 2020.

5 South African Cultural Observatory, 'Minister Mthethwa Interaction with the Creative Industries', 2018. https://www.southafricanculturalobservatory.org.za/article/ministermthethwa-interaction-with-the-creative-industries, accessed 13 May 2020; South African Government, 'Mzansi's Golden Economy: Contribution of the Arts, Culture and Heritage Sector to the New Growth Path', 2011. https://www.gov.za/documents/mzansis-goldeneconomy-contribution-arts-culture-and-heritage-sector-new-growth-path, accessed 27 June 2012.

6 Department of Environmental Affairs and Tourism, 'National Environmental Management Act 107 of 1998', Government Gazette, 401 (19519) 1998. www.environment.gov.zal sites/default/files/legislations/nema amendment act107.pdf, accessed on 15 May 2020; Department of Environmental Affairs, 'Climate Change Bill, 2018', Government Gazette, 636 (41689) 2018. www.environment.gov.za/sites/default/files/legislations/ climatechangebill2018 gn41689.pdf, accessed 15 May 2020.

7 Sipho Kings, 'New Bill Gives Mines Carte Blanche', Mail and Guardian 27 March 2014. https://mg.co.za/article/2014-03-27-new-bill-gives-mines-carte-blanche/, accessed 18 November 2014; Sipho Kings, 'Water be Damned, The Mines Are What Count', Mail and Guardian 19 November 2015. https://mg.co.za/article/2015-11-19-water-be-damned-themines-are-what-count/, accessed 24 January 2020. 
8 Lisa Steyn, 'Eskom Gridlocks Renewable Energy', Mail and Guardian 30 October 2015. http:// mg.co.za/article/2015-10-29-eskom-gridlocks-renewable-energy, accessed 11 January 2016; Mashadi Kekana, 'Mpumalanga Tops World Nitrogen Dioxide Air Pollution Charts', Mail and Guardian 30 October 2018. https://mg.co.za/article/2018-10-30-mpumalangatops-world-nitrogen-dioxide-air-pollution-charts, accessed 20 November 2018.

9 Kevin Davie, 'SA, Like Others, Flunks Emissions Report Card', Mail and Guardian Business 12 November 2019. https://mg.co.za/article/2019-11-12-00-sa-like-othersflunks-emissions-report-card/, accessed 27 January 2020; World Economic Forum, 'The Deadly Link Between COVID-19 and Air Pollution', 15 April 2020. https://www.weforum. org/agenda/2020/04/the-deadly-link-between-covid-19-and-air-pollution/, accessed 15 May 2020; Christi Nortier, C. (2020) 'Air Pollution Drops, Illegal Cigarette Trade Spikes and Schools Approach Reopening', Maverick Citizen 11 May 2020. https://www.dailymaverick. co.za/article/2020-05-11-air-pollution-drops-illegal-cigarette-trade-spikes-and-schoolsapproach-reopening/, accessed 15 May 2020.

10 Respondent 3, interview by author, typed questionnaire, 12 July 2018, Grahamstown.

11 Respondent 2, interview by author, typed questionnaire, 1 June 2018, Pretoria.

12 Sabelo Skiti, 'Sad Monument a Blot on Memory of Cradock Four', Sunday Times 15 May 2015. https://www.timeslive.co.za/sunday-times/news/2015-05-24-sad-monumenta-blot-on-memory-of-cradock-fourl, accessed 30 April 2019; Derrick Spies, 'Cradock Four Memorial Neglected, Forgotten', News 247 April 2015. https://www.news24.com/ SouthAfrica/News/Cradock-Four-memorial-neglected-forgotten-20150407, accessed 30 April 2019; Leigh Paulse, 'Sarah Baartman Remembrance Centre Project at Standstill', SABC News 15 January 2019. http://www.sabcnews.com/sabcnews/sarah-baartmanremembrance-centre-project-at-standstill/, accessed 28 January 2019.

13 Respondent 5, interview, 10 May 2018.

14 Respondent 11, interview by author, typed questionnaire, 4 June 2018, Pretoria.

15 Respondent 6, interview by author, typed questionnaire, 27 June 2018, East London.

16 Respondent 11, interview, 4 June 2018; Respondent 12, interview by author, typed questionnaire, 5 June 2018, Grahamstown.

17 Respondent 8, interview by author, typed questionnaire, 10 May 2018, Cape Town; Respondent 1, interview by author, typed questionnaire, 6 June 2018, Grahamstown.

18 Respondent 1, interview, 6 June 2018.

19 Respondent 5, interview, 10 May 2018.

20 Respondent 2, interview, 1 June 2018.

21 Respondent 14, interview by author, typed questionnaire, 5 July 2018, Grahamstown.

22 International Council of Museums, 'Museum Definition', 2007. https://icom.museum/en/ activities/standards-guidelines/museum-definition/, accessed 16 July 2019.

23 Sandahl, 'Report and Recommendations'; Jette Sandahl, 'Definitions Are Dynamic, Not Static', Museums Association, 5 December 2019. https://www.museumsassociation. org/museums-journal/comment/01122019-definitions-are-dynamic-not-static?utm campaign=1644717 12122019\&utm medium=email\&utm source=Museums $\% 20$ Association\&dm i=2VBX,Z92L,7AK7Z8,3PDZT,1, accessed on 13 December 2019. 


\section{References}

Abungu, G. (2004) 'Democratising Museums and Heritage Ten Years On', South African Museums Association Bulletin, 40 3-5.

Adjor, D.M. and Kebalo, L. (2018) 'Does Corruption Matter for Unemployment in SADC Countries?', Review of Economic and Business Studies, 11 (1) 65-92. DOI 10.1515/ rebs-2018-0074.

Allen, F. (2015) 'The State of the Climate Justice Movement in South Africa', Capitalism Nature Socialism, 26 (2) 46-57. DOI: 10.1080/10455752.2015.1017731.

Alonso, M.F. (2008) 'Can We Protect Traditional Knowledges?', in Boaventura de Sousa Santos (ed) Another Knowledge Is Possible: Beyond Northern Epistemologies, 24971, New York: Verso.

Anderies, J.M., Janssen, M.A. and Ostrom, E. (2004) 'A Framework to Analyze the Robustness of Social-ecological Systems from an Institutional Perspective', Ecology and Society, 9 (1) https://www.jstor.org/stable/26267655. 
Bakker, K.A. and Müller, L. (2010) 'Intangible Heritage and Community Identity in PostApartheid South Africa', Museum International, 62 (1) 48-56.

Ballantyne, R. and Uzzel, D. (2011) 'Looking Back and Looking Forward: The Rise of the Visitor-Centered Museum', Curator, 54 (1) 85-92.

Bhaskar, R. (1998) The Possibility of Naturalism: A Philosophical Critique of the Contemporary Human Sciences, London: Routledge.

(2008) Dialectic: The Pulse of Freedom. London: Verso.

(2010) 'Contexts of Interdisciplinarity: Interdisciplinarity and Climate Change', in Roy Bhaskar, Cheryl Frank, Karl Georg Høyer, Petter Næss and Jenneth Parker (eds) Interdisciplinarity and Climate Change: Transforming Knowledge and Practice for our Global Future, 1-24, London: Routledge.

Bhaskar, R. and Parker, J. (2010) 'Introduction', in Roy Bhaskar, Cheryl Frank, Karl Georg Høyer, Petter Næss and Jenneth Parker (eds) Interdisciplinarity and Climate Change: Transforming Knowledge and Practice for our Global Future, vii-xiii, London: Routledge.

Cameron, F. (2015a) 'Ecologizing Experimentations: A Method and Manifesto for Composing a Post-humanist Museum', in Fiona R. Cameron and Brett Neilson (eds) Climate Change and Museum Futures, 16-33, London: Routledge.

Cameron, F. (2015b) 'The Liquid Museum: New Institutional Ontologies for a Complex, Uncertain World', in Andrea Witcomb and Kylie Message (eds) The International Handbooks of Museum Studies: Museum Theory, 345-61, Milton: John Wiley and Sons.

Colding, J., Barthel, S. and Sörqvist, P. (2019) 'Wicked Problems of Smart Cities', Smart Cities, 2 512-21. doi:10.3390/smartcities2040031.

Corsane, G. (2000) 'What can South African Museums Learn from the Work of the French Sociologist Pierre Bourdieu?', South African Museums Association Bulletin, 24 (1) 25-30.

(2004) 'Transforming Museums and Heritage in Postcolonial and Post-Apartheid South Africa: The Impact of Processes of Policy Formulation and New Legislation', Social Analysis, 48 (1) 5-15.

Crutzen, P.J. (2002) 'Geology of Mankind', Nature, 41523.

De Sousa Santos, B. (2018) The End of the Cognitive Empire: The Coming of Age of Epistemologies of the South, London: Duke University Press.

Dondolo, L. (2005) 'Museums and Communities: The Reconstruction of Museums and their Practices in Post-apartheid South Africa', South African Museums Association Bulletin, 31 68-71.

Dubin, S.C. (2006) Transforming Museums: Mounting Queen Victoria in a Democratic South Africa, New York: Palgrave MacMillan.

Fletcher, A.J. (2017) 'Applying Critical Realism in Qualitative Research: Methodology Meets Method', International Journal of Social Research Methodology, 20 (2) 181194. DOI: $10.1080 / 13645579.2016 .1144401$.

Fox, W.L. (2017) 'The Art of the Anthropocene', in Jennifer Newell, Libby Robin and Kirsten Wehner (eds) Curating the Future: Museums, Communities and Climate Change, 196-205, London: Routledge. 
Frank, C. (2010) 'Global Warming and Cultural/Media Articulations of Emerging and Contending Social Imaginaries: A Critical Realist Perspective', in Roy Bhaskar, Cheryl Frank, Karl Georg Høyer, Petter Næss and Jenneth Parker (eds) Interdisciplinarity and Climate Change: Transforming Knowledge and Practice for our Global Future, 100-15, London: Routledge.

Hartwig, M. (2008) 'Introduction', in Roy Bhaskar, Dialectic: The Pulse of Freedom, xiiixxxii, New York: Routledge.

Hawkins, G. (2009) 'More-than-Human Politics: The Case of Plastic Bags', Australian Humanities Review, 46 41-54.

Helland, L.E.F. and Lindgren, T. (2016) 'What Goes Around Comes Around: From the Coloniality of Power to the Crisis of Civilization', Journal of World-Systems Research, 22 (2) 430-62.

Herbert, D.G. (2000) 'Natural Science in Museums: Life Between a Rock and a Hard Place', South African Museums Association Bulletin, 24 (1) 80-4.

Jeffery, T. (2017) 'Future-Proofing South Africa's Cultural Museums: Climate Change, Heritage Discourse and Cultural Landscapes', South African Museums Association Bulletin, 39 19-28.

Kamga, S.A.D. and Heleba, S. (2012) 'Can Economic Growth Translate into Access to Rights? Challenges Faced by Institutions in South Africa in Ensuring that Growth Leads to Better Living Standards', International Journal on Human Rights, 9 (17) 83-106.

Keene, S. (2006) 'All That is Solid? Museums and the Postmodern', Public Archaeology, 5 (3) $185-98$.

Khan, F. (2000) 'Environmentalists, Museologists and Communities: Partners in the Conservation of Heritage', South African Museums Association Bulletin, 24 (1) 50-4.

Levitz, C. and Mathers, K. (2000) 'A Poverty of Theory, A Wealth of Activity: Museology and South African Museums', South African Museums Association Bulletin, 24 (1) 18-21.

Lotz-Sisitka, H. (2016) 'Absenting Absence: Expanding Zones of Proximal Development in Environmental Learning Processes', in Leigh Price and Heila Lotz-Sisitka (eds) Critical Realism, Environmental Learning and Social-Ecological Change, 318-39, London: Routledge.

Lotz-Sisitka, H. and Price, L. (2016) 'Why Critical Realism, Environmental Learning and Social-Ecological Change? Introducing the Book', in Leigh Price and Heila LotzSisitka (eds) Critical Realism, Environmental Learning and Social-Ecological Change, 1-17, London: Routledge.

Lotz-Sisitka, H., Wals, A.E.J., Kronlid, D. and McGarry, D. (2015) 'Transformative, Transgressive Social Learning: Rethinking Higher Education Pedagogy in Times of Systemic Global Dysfunction', Current Opinion in Environmental Sustainability, 16 73-80. doi.org/10.1016/j.cosust.2015.07.018.

Macdonald, S. (2015) 'Is "Difficult Heritage" Still Difficult? Why Public Acknowledgment of Past Perpetration May No Longer Be So Unsettling to Collective Identities', Museum International, 67 (1-4) 6-22. 
Mahony, E. (2017) 'Opening Spaces of Resistance in the Corporatized Cultural Institution: Liberate Tate and the Art Not Oil Coalition', Museum and Society, 15 (2) 126-41.

Marschall, S. (2005) 'Making Money with Memories: The Fusion of Heritage, Tourism and Identity Formation in South Africa', Historia, 50 (1) 103-22.

Martin, M. (2000) 'Theory into Practice, Practice into Theory', South African Museums Association Bulletin, 24 (1) 11-7.

Mdanda, S. (2016) 'Museums and Democratic Education: How Museums were Transformed after the 1994 Elections in South Africa', South African Museums Association Bulletin, 38 (1) 47-57.

Meskell, L. (2012) The Nature of Heritage: The New South Africa, Chicester: WileyBlackwell.

Mngqolo, S. (2010) 'Voices Within our Exhibitions', South African Museums Association Bulletin, 33 (1) 70.

Molobela, I.P. and Sinha, P. (2012) 'Management of Water Resources in South Africa: A Review', African Journal of Environmental Science and Technology, 5 (12) 9931002. DOI: $10.5897 / A J E S T 11.136$.

Moore, J.W. (2017) 'The Capitalocene, Part I: On the Nature and Origins of our Ecological Crisis', The Journal of Peasant Studies, 44 (3) 594-630. DOl:10.1080/03066150.20 16.1235036.

Morgan, J. and Macdonald, S. (2020) 'De-Growing Museum Collections for New Heritage Futures', International Journal of Heritage Studies, 26 (1) 56-70. DOl:10.1080/13527 258.2018.1530289.

Mosely, E. (2007) 'Visualizing Apartheid: Contemporary Art and Collective Memory during South Africa's Transition to Democracy', Antipoda, 5 97-119.

Mukute, M. (2016) 'Dialectical Critical Realism and Cultural Historical Activity Theory (CHAT): Exploring and Expanding Learning Processes in Sustainable Agriculture Workplace Contexts', in Leigh Price and Heila Lotz-Sisitka (eds) Critical Realism, Environmental Learning and Social-Ecological Change, 190-211, New York: Routledge.

Munnik, V. (2016) 'Steel Valley and the Absence of Environmental Justice in the New South Africa: Critical Realism's Kinship with Environmental Justice', in Leigh Price and Heila Lotz-Sisitka (eds) Critical Realism, Environmental Learning and SocialEcological Change, 293-317, London: Routledge.

Nattrass, N. (2014) 'A South African Variety of Capitalism?', New Political Economy, 19 (1) 56-78. DOI: 10.1080/13563467.2013.768610.

Newell, J., Robin, L. and Wehner, K. (2017) 'Introduction', in Jennifer Newell, Libby Robin and Kirsten Wehner (eds) Curating the Future: Museums, Communities and Climate Change, 1-16, London: Routledge.

Nixon, R. (2017) 'The Anthropocene and Environmental Justice', in Jennifer Newell, Libby Robin and Kirsten Wehner (eds) Curating the Future: Museums, Communities and Climate Change, 23-31, London: Routledge.

Norrie, A. (2010) Dialectic and Difference: Dialectical Critical Realism and the Grounds of Justice, London: Routledge. 
O'Donoghue, R. (2016) 'Working with Critical Realist Perspective and Tools at the Interface of Indigenous and Scientific Knowledge in a Science Curriculum Setting', in Leigh Price and Heila Lotz-Sisitka (eds) Critical Realism, Environmental Learning and Social-Ecological Change, 159-77, London: Routledge.

Palermo, G. (2007) 'The Ontology of Economic Power in Capitalism: Mainstream Economics and Marx', Cambridge Journal of Economics, 31 (4) 539-61. doi. org/10.1093/cje/bel036.

Pearce, S.M. (2003) Interpreting Objects and Collections, London: Routledge.

Pendlebury, J. (2013) 'Conservation Values, the Authorised Heritage Discourse and the Conservation-Planning Assemblage', International Journal of Heritage Studies, 19 (7) $709-27$.

Phillips, R.B. (2019) “"Making Fun” of the Museum: Multi-disciplinarity, Holism, and the "Return of Curiosity"', Museum and Society, 17 (3) 316-41.

Plumwood, V. (2002) 'Decolonising Relationships with Nature', Philosophy Activism Nature, 2 7-30.

Potter, G. (2001) 'Truth in Fiction, Science and Criticism', in Jósé Lopez and Garry Potter (eds) After Postmodernism: An Introduction to Critical Realism, 183-95, London: Athlone Press.

Price, L. (2016) 'Key Critical Realist Concepts for Environmental Educators', in Leigh Price and Heila Lotz-Sisitka (eds) Critical Realism, Environmental Learning and SocialEcological Change, 18-39, London: Routledge.

Rall, M. (2018) 'Across Time of Three South African San Exhibitions: Reflecting on Colonialism, Apartheid and Decolonisation', South African Museums Association Bulletin, 40 (1) 11-22.

Rankin, E. (2013) 'Creating/Curating Cultural Capital: Monuments and Museums for PostApartheid South Africa', Humanities, 2 72-98. doi:10.3390/h2010072.

Rassool, C. (2000) 'The Rise of Heritage and the Reconstitution of History in South Africa', Kronos, 26 (1) 1-21.

(2016) 'Red Mandela: Contests of Auto-biography and Auto/biography in South Africa', Kronos, 42 195-213.

Reddy, T. (2013). 'Coal3 will be Another Eskom Catastrophe', Mail and Guardian, 27 September, 44.

Robin, L., Avango, D., Keogh, L., Möllers, N and Trischler, H. (2017) 'Displaying the Anthropocene In and Beyond Museums', in Jennifer Newell, Libby Robin and Kirsten Wehner (eds) Curating the Future: Museums, Communities and Climate Change, 252-66, London: Routledge.

Rosenberg, E. (2020a) 'Synthesis and Elaboration of Critical Realist Methodology for Green Skills Research', in Eureta Rosenberg, Presha Ramsarup and Heila LotzSisitka (eds) Green Skills Research in South Africa: Models, Cases and Methods, 192-207, Abingdon: Routledge.

Rosenberg, E. (2020b) 'Special Issue: Education for Sustainability in a Time of Crises. Editorial Part 1', Southern African Journal of Environmental Education, 36 1-7. DOI 10.4314/sajee.v36i1.1. 
Rossi, U. (2012) 'On the Varying Ontologies of Capitalism: Embeddedness, Dispossession, Subsumption', Progress in Human Geography, 37 (3) 348-65.

Roux, N. (2018) "'A House for Dead People": Memory and Spatial Transformation in Red Location, South Africa', Social \& Cultural Geography, 19 (4) 407-28. DOI: 10.1080/14649365.2017.1280614.

Sabai, D. (2016) 'Indigenous Knowledge and Critical Realism on the Eastern Coast of Tanzania', in Leigh Price and Heila Lotz-Sisitka (eds) Critical Realism, Environmental Learning and Social-Ecological Change, 178-89, London: Routledge.

Schudel, I.J. (2017). 'Modelling Dialectical Processes in Environmental Learning: An Elaboration of Roy Bhaskar's Onto-axiological Chain', Journal of Critical Realism, 16 (2) 163-183. DOl:10.1080/14767430.2017.1288061.

Scott, D. (2010) Education, Epistemology and Critical Realism, London: Routledge.

Scott, D. and Oelofse, C. (2005) 'Social and Environmental Justice in South African Cities: Including 'Invisible Stakeholders' in Environmental Assessment Procedures', Journal of Environmental Planning and Management, 48 (3) 445-67. DOI:10.1080/09640560500067582.

Shoba, N. (2005) 'Community Museums: An Insight into the Socio-Economic, Environmental and Cultural Impacts on Community Museums in the Eastern Cape', South African Museums Association Bulletin, 3126.

Smith, C. (2014) 'Post-Modernising the Museum: The Ration Shed', Historical Encounters, 1 (1) 32-49.

Soudien, C. (2008) 'Emerging Discourses Around Identity In New South African Museum Exhibitions', Interventions, 10 (2) 207-21. DOI:10.1080/13698010802145119.

Thomas, N. (2010) 'The Museum as Method', Museum Anthropology, 33 (1) 6-10. DOI: 10.1111/j.1548-1379.2010.01070.x.

(2016) The Ascendancy of the Museum, London: Reaktion.

Togo, M. (2016) 'Underlabouring Systems Thinking with Critical Realism in Understanding Rhodes University's Response to the Sustainability Imperative', in Leigh Price and Heila Lotz-Sisitka (eds) Critical Realism, Environmental Learning and SocialEcological Change, 85-97, London: Routledge.

van Rooyen, J., de Lange, M. and Hassan, R. (2011) 'Water Resource Situation, Strategies and Allocation Regimes in South Africa', in Barbara Schreiner and Rashid Hassan (eds) Transforming Water Management in South Africa: Designing and Implementing a New Policy Framework, 19-32, Pretoria: Springer.

Venugopal, R. (2015) 'Neoliberalism as Concept', Economy and Society, 44 (2) 165-87. DOI: $10.1080 / 03085147.2015 .1013356$.

Vergo, P. (1989) 'Introduction', in Peter Vergo (ed) The New Museology, 1-5, Bath: Reaktion. 
Vollgraaff, H. (2004) 'Editorial', South African Museums Association Bulletin, 30 (1) 2.

(2012) 'Museum Practice: Rooted in Social Space', South African Museums Association Bulletin, 35 31-5.

(2018) 'Revitalising the South African Museum Sector: New Museological Trends', in Patrick Ngulube (ed) Handbook of Research on Heritage Management and Preservation, 372-95, Hershey PA: IGI Global.

von Weizsäcker, E.U. and Wijkman, A. (2018) Come On! Capitalism, Short-termism, Population and the Destruction of the Planet, New York: Springer.

Walker, B., Holling, C.S., Carpenter, S.R. and Kinzig, A. (2004) 'Resilience, Adaptability and Transformability in Social-ecological Systems', Ecology and Society, 9 (2) https://www.jstor.org/stable/26267673.

Wehner, K. (2017) 'Towards an Ecological Museology: Responding to the Animal-Objects of the Australian Institute of Anatomy Collection', in Jennifer Newell, Libby Robin and Kirsten Wehner (eds) Curating the Future: Museums, Communities and Climate Change, 85-100, London: Routledge.

Weil, S. (1999) 'From Being About Something to Being For Somebody: The Ongoing Transformation of the American Museum', Daedalus, 128 (3) 229-58.

Wells, H.G. (1898) The War of the Worlds, New York: Dover.

Witz, L., Rassool, C. and Minkley, G. (2001) 'Repackaging the Past for South African Tourism', Daedalus, 130 (1) 277-96.

Wray, L. (2019) 'Taking a Position: Challenging the Anti-Authorial Turn in Art Curating', in Robert R. Janes and Richard Sandell (eds) Museum Activism, 315-25, London: Routledge.

Zuma, B. (2018) 'The Extent to which South African Museums Surrendered to Political Undertones', Museum International, 70 (3-4) 38-47. doi.org/10.1111/muse.12208.

\section{Author}

Tom Jeffery is Curator of Exhibitions at Amazwi South African Museum of Literature, and a PhD scholar at the Environmental Learning Research Centre at Rhodes University, South Africa. His research explores ways in which critical realist philosophy might contribute to the integration of social-ecological issues into museum theory and practice. He is particularly interested in the ways in which the current trends towards decolonization and ecologization of museum work may intersect in an eco-decolonial form of theory and practice.

Amazwi South African Museum of Literature

25A Worcester Street

Makhanda / Grahamstown

South Africa

Environmental Learning Research Centre

Lucas Avenue

Makhanda / Grahamstown

South Africa

Tel: 0466227042 